\title{
Microbial digestion of complex carbohydrates in man
}

\section{By John H. Cummings, Dunn Clinical Nutrition Centre, Addenbrooke's Hospital, Trumpington Street, Cambridge $C B 2$ I $Q E$}

There is now substantial evidence that a fermentative process similar to that occurring in non-ruminant herbivorous and in omnivorous species takes place also in the human large intestine. Its metabolic significance, however, is by no means certain. The principal fermentable substrate available in the human colon is probably the polysaccharide fraction of plant cell walls, currently referred to as dietary fibre. In the UK this amounts to only $15^{-20} \mathrm{~g} / \mathrm{d}$ (Bingham et al. 1979) and in many Western countries rarely exceeds $30 \mathrm{~g}$ on average (Bingham $\&$ Cummings, I 980 ). This represents only $3-4 \%$ of dry matter intake which, when contrasted with the $10-20 \%$ of fermentable carbohydrate in the diet of species such as the pig or horse, makes it easy to appreciate why this property of the gut has been neglected in man.

A fairly limited view of colonic function has traditionally been taken by medical science. The large intestine is usually thought of as an organ for the conservation of salt and water and for the orderly disposal of waste products from the body. The notion that it might be an important metabolic structure with influence outside its walls has not been seriously considered in recent years, with occasional notable exceptions (Wrong, 1971). Furthermore, the ability of the human species to survive in reasonable health after removal of the colon has confirmed in many their belief of its rudimentary function and importance (Ritchie, 1971; McNeil et al. 1982). Of the occurrence of colonic fermentation in man, however, there can be little doubt.

\section{Occurrence of cell-wall polysaccharide breakdown in man}

For more than 100 years it has been known that 'fibre' was digested in man. Around the turn of the century considerable interest was being taken in cellulose breakdown by Rubner and others (see review, Mangold, 1934). Of more recent studies that of Williams \& Olmsted (1936) is one of the most notable. They reported dietary experiments with three medical students to whom they gave cell-wall preparations from carrot, cabbage, peas, bran, lucerne (Medicago sativa) and also cellulose and agar. With most of the preparations only $20 \%$ of the hemicellulose (non-cellulosic polysaccharide; NCP) fraction fed could be recovered in the stools although more than $60 \%$ from bran survived breakdown. Cellulose appeared to be less digestible but even so about $50 \%$ disappeared during passage through the gut.

Since the I930s, methods for the measurement of plant cell-wall polysaccharides have improved considerably and this has led to a greater understanding of their metabolism, but the over-all conclusion, that substantial breakdown occurs, 

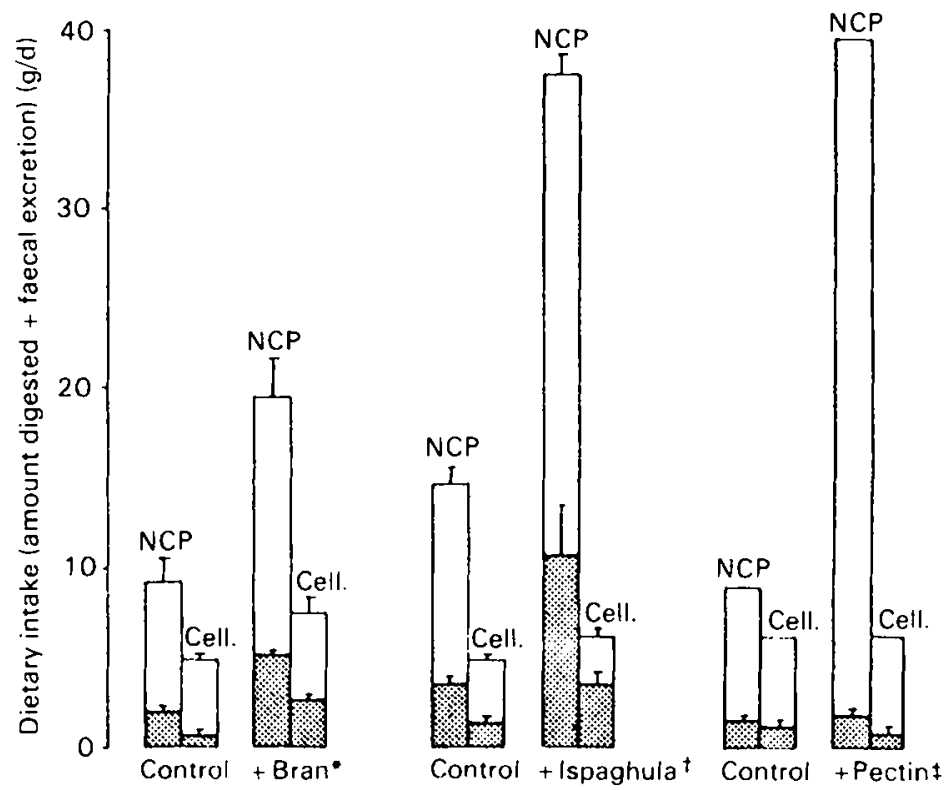

Fig. I. Dietary intake (amount digested $(\square)$ plus faecal excretion (iㅏ)) of the principal cell-wall polysaccharides, cellulose (Cell.) and non-cellulosic polysaccharides (NCP), in three groups of healthy human volunteers given typical UK diets under controlled conditions (Control) and then the same diet with the addition of either bran, ispaghula or pectin. From "Southgate et al. (1976), $\nmid$ Prynne \& Southgate (1979), $\ddagger$ Cummings et al. (1979).

remains. Fig. I shows the results of three recent studies of groups of healthy adults in which dietary cellulose and NCP intakes and faecal excretion of these polymers have been measured using the techniques of Southgate (1976). Both the cellulose and NCP from the control diets (which were typical mixed UK diets) are extensively degraded. The cell-wall polysaccharides in added bran are partly degraded, in ispaghula substantially and the pectin completely so.

The relative resistance of bran to digestion has been noted by others (Heller et al. 1980 ; Stephen \& Cummings, I980a). Its poor digestibility in human dietary studies is one example of the wide variability that occurs in fermentable polysaccharide breakdown. In ruminant nutrition this variability has important physiological, and economic, implications but in man it has received little attention. A number of chemical and physical characteristics of these polysaccharides may influence their breakdown including, for example, the extent of lignification of the cell-wall polymers (bran cell-walls being one of the most lignified of human foods), their water solubility (generally water-soluble polysaccharides such as pectin are highly digestible), associated silica and cuticular substances (which are thought to inhibit breakdown in the rumen), particle size (the finer the particle the more readily digestible), molecular structure, the level of intake, food processing (for example, heating and drying) and possibly previous diet. Host factors affecting breakdown will include the type of gut microflora and transit time (see review, Cummings I982). 


\section{Site of breakdown}

The evidence, therefore, that the complex carbohydrates of the plant cell-wall are broken down in the human gut is quite clear. The principal site of this breakdown is widely assumed, probably correctly, to be the large intestine, although in fact little experimental work has been done to document this. One method of obtaining evidence for the site of breakdown of these polysaccharides is to feed them to people who have an ileostomy. These are subjects whose large intestine has been removed, usually on account of inflammatory bowel disease, and an exit to the terminal ileum made on the anterior abdominal wall. Sandberg et al. ( 1981 ) gave $16 \mathrm{~g}$ bran daily to each of nine subjects with an ileostomy. They were able to recover about $88 \%$ of the hemicelluloses in the ileostomy effluent. Although bran is relatively poorly digested during passage through the entire gut the almost complete recovery of the more digestible of its cell-wall polysaccharides from the terminal ileum indicates that any breakdown which does occur is probably in the colon. Holloway et al. (1980), however, were able to recover only $35 \%$ of the hemicelluloses from mixed diets given to female ileostomists and $17 \%$ from males, suggesting substantial small bowel degradation. Similarly $15 \%$ of pectin in women and $47 \%$ in men could not be recovered in a further series of studies (Holloway et al. 1983). In contrast, Werch \& Ivy (194I) had found little evidence for pectin breakdown in the small bowel of man. Further studies by Holloway et al. (1978), using the same ileostomy model as for their pectin and hemicellulose experiments, had shown no significant degradation of the cellulose and hemicellulose of bran. Work by McLean-Ross et al. ( $198 \mathrm{I}$ ) in which gum arabic was incubated with gastric juices in vitro has not shown evidence of significant breakdown of this polysaccharide, whilst in our own studies (H. N. Englyst and J. H. Cummings, unpublished results) with cereals, complete recovery from ileostomy effluent of cell-wall polysaccharides has been achieved. The contrasting results in these studies are probably a reflection of the methodological difficulties both in the use of the ileostomy model and in accurate measurement of dietary polysaccharides especially in the presence of gut contents. That the colon is the main site of breakdown of these polysaccharides can be deduced from the absence of digestive enzymes in the human small bowel known to hydrolyse plant cell-wall polysaccharides, of a significant microflora and of signs of fermentation such as appreciable concentrations of short-chain fatty acids in this part of the gut.

The human colon contains a substantial mixed culture of bacteria estimated at $10^{10}-10^{11} / \mathrm{g}$ colonic and faecal material, $99 \%$ of which are anaerobes (Moore et al. 1978). Most of these organisms are saccharolytic, that is they derive their energy primarily from carbohydrate and its derivatives (Miller \& Wolin, 1979). Many species isolated from the human colon have been shown to ferment hemicellulose, cellulose and pectins. The considerable work done by Salyers and her colleagues in this field has been recently reviewed (Salyers, 1983 ).

The presence of acetic, propionic and butyric acids in the colon is clear evidence of fermentation. These acids are the principle anions in human colonic contents and faeces at concentrations of $60-100 \mathrm{mmol} / \mathrm{kg}$ and molar ratios for acetate: 
propionate:butyrate of about $60: 25: 15$ (Cummings, $198 \mathrm{I}$ ). These are similar ratios to those found in species where fermentation is known to be an important part of normal digestive physiology. Other end-products of fermentation, the gases carbon dioxide, hydrogen and methane, are also produced in man. Their excretion per rectum may on occasion be a source of social discomfort but since hydrogen and methane are not produced by mammalian cells they provide further evidence for the fermentative process.

The balance of evidence therefore is in favour of fermentation, the anaerobic breakdown of carbohydrate, occurring in the human colon. In fact this is probably the principal metabolic event in this organ and as such is unique to the human body. What is its significance? In terms of the metabolism of the microflora it is considerable.

\section{Fermentation and the microflora}

Bacteria in the colon metabolize carbohydrate, and possibly other substrates, in order to obtain energy for growth and for the maintenance of cellular activity. There are, however, considerable difficulties in documenting microbial metabolism in man. Most studies of human colonic microflora have relied on examination of faeces using the classical techniques of taxonomic bacteriology. The use of faeces for this purpose is understandable in view of the problems in obtaining reliable samples from the colonic lumen but raises the question of how representative are faecal bacteria of the microflora in other regions of the colon?

In separate studies Moore et al. (1978) and Croucher et al. (1983) have examined the flora in different areas of the colons of the victims of sudden death. Both groups conclude that there are no detectable regional differences using classical methods, within the colon of man. Moreover the flora associated with the mucosal surface do not seem to be significantly different from those in the lumen of the bowel. Accepting, therefore, the possible limitations in the use of faecal flora as a guide to colonic flora, a number of studies of the effect of diet may be noted. No change in total bacterial counts nor in the numbers or distribution of species have been found in healthy subjects given bran (Drasar et al. 1976; Fuchs et al. 1976), bagasse (Walters et al. 1975), guar gum (Drasar \& Jenkins, 1976) and pectin (Doyle et al. I98I) when compared with a control low-fibre diet. This apparent stability of the colonic microflora to dietary change, not only in fibre content but also to changes in fat and protein, has led to the suggestion that the methods of classical bacteriology are not sensitive enough to detect differences and that alternative methods are required.

Studies of the 'metabolic' activity of micro-organisms in faeces by measurement of faecal microbial enzymes have, to date, been inconclusive (Cummings, 1983 ) but changes have been observed in the microflora using a gravimetric method derived from animal nutrition for determining microbial mass in gut contents (Stephen \& Cummings, $1980 b$ ). Other chemical markers of microbial activity such as DNA, RNA, ATP and diaminopimelic acid have not been used in man to any significant extent as yet. 
Using the gravimetric method it has been observed in man that feeding fermentable carbohydrate stimulates microbial growth and increases microbial cell excretion in faeces. Fig. 2 shows the effect on daily faecal microbial cell mass excretion of three different plant cell-wall preparations given to groups of healthy subjects. These studies were carried out with volunteers living in a metabolic unit and eating controlled diets containing about $20 \mathrm{~g}$ plant cell-wall polysaccharides from mixed sources daily for 3 weeks and then for a further 3 -week period the same diet with the addition of between 14 and $19 \mathrm{~g}$ polysaccharide from cabbage, carrot or bran. It is evident from Fig. 2 that each type of fibre leads to a significant increase in the daily excretion of microbial material, the increase being $4.8 \mathrm{~g}(33 \%)$ for cabbage, $3.8 \mathrm{~g}(25 \%)$ for carrot and $2.3 \mathrm{~g}(15 \%)$ for bran. The increase with bran is less than that for the other two, probably because the cell-wall polysaccharides in bran resist breakdown by the microflora to a much greater extent than those in cabbage or carrot. Of the $18.3 \mathrm{~g}$ cabbage fibre fed daily only $\mathrm{I} .6 \mathrm{~g} / \mathrm{d}$ could be recovered in faeces, i.e. $16.3 \mathrm{~g} / \mathrm{d}$ was fermented $(89 \%)$; for carrot $17.4 \mathrm{~g} / \mathrm{d}$ $(90 \%)$ was fermented but for bran only $6.4 \mathrm{~g} / \mathrm{d}$ could not be recovered $(45 \%$ fermented). Providing fermentable substrate to colonic bacteria therefore leads to a stimulation in their growth and metabolic activity.

\section{Control}

The control of fermentation is of considerable significance in the over-all function of the human large intestine. The amount of substrate available is one important factor determining microbial cell growth but because of the difficulties in studying bacterial metabolism in vivo only approximate values are available for the flow of substrate through the complex and varied routes of fermentation in man (Cummings, I981). One control over fermentation which has been well

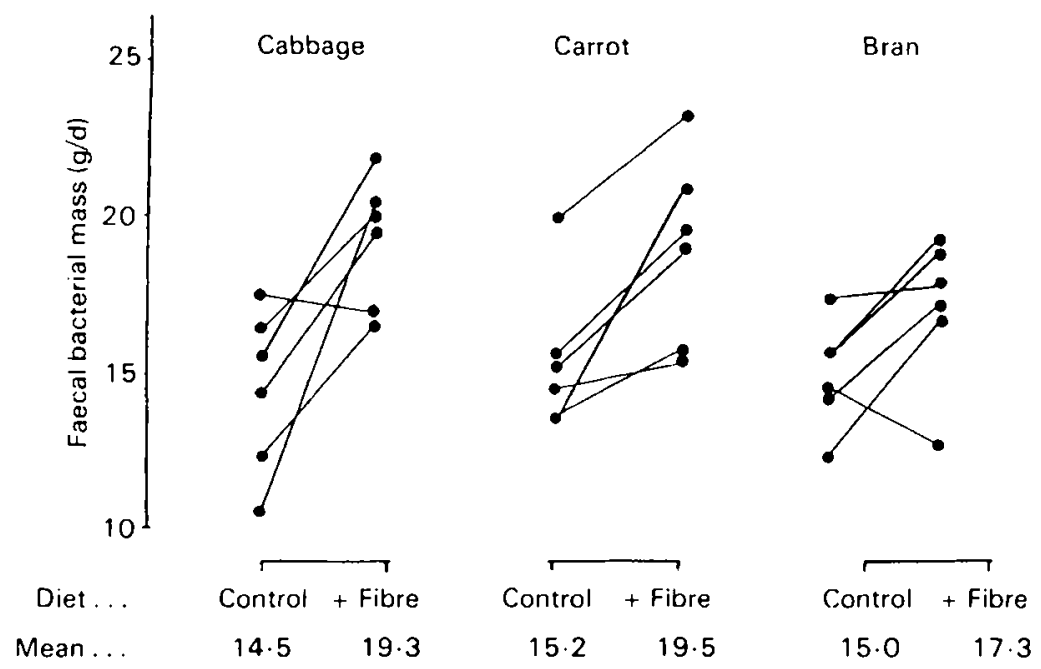

Fig. 2. Mean daily faecal excretion of microbial solids in three groups of healthy volunteers given a typical UK diet containing about $20 \mathrm{~g}$ cell-wall polysaccharides for a 3 -week period and then the same diet with the addition of $18.3 \mathrm{~g}$ cell-wall polysaccharides from cabbage, or $19.3 \mathrm{~g}$ from carrot or $14.2 \mathrm{~g}$ from bran. From Stephen \& Cummings (1980a) and J. Banwell (unpublished results). 
documented in vitro is the dilution rate or turnover time (Hespel, 1979; Hespel \& Bryant, 1979). In the studies of Isaacson et al. (1975), mixed populations of anaerobic rumen bacteria were grown in vitro in continuous culture with glucose as the only energy source. The yield of microbial cells per mol glucose fermented (efficiency of conversion) increased from $4^{2} \mathrm{~g}$ cells $/ \mathrm{mol}$ at a dilution rate of $0.02 / \mathrm{h}$ (turnover time of $50 \mathrm{~h}$ ) to $84 \mathrm{~g}$ cells $/ \mathrm{mol}$ glucose at $0.12 / \mathrm{h}$ (turnover time $8.3 \mathrm{~h}$ ). On a simple weight basis the yield of microbial matter ranged from 230 to $460 \mathrm{~g} / \mathrm{kg}$ carbohydrate fermented. Salyers and colleagues (Salyers et al. 1981; Kotarski \& Salyers, I98I) have shown, using very similar techniques but with single strains of human colonic bacteroides, that cell yields are of the same order, $30-40 \%$, when either glucose or an arabinogalactan is the primary energy source. At a turnover time of $32 \mathrm{~h}$, cell yields were $60 \mathrm{~g} / \mathrm{mol}$ glucose rising to $75 \mathrm{~g} / \mathrm{mol}$ glucose at $8 \mathrm{~h}$. In these studies the more rapid the turnover the greater the efficiency of fermentation due to diminished requirements by the bacteria for maintenance energy (Owens \& Isaacson, I977).

In man turnover of gut contents, or transit time as it is more usually called, has been measured by both continuous- and intermittent-marker methods and averages $48-72 \mathrm{~h}$ in normal subjects living in the UK (Cummings, 1978; Wyman et al. 1978; Eastwood et al. 1982). Of this about $40-60 \mathrm{~h}$ will be spent in the large intestine. Stephen \& Cummings (I98I) have taken a group of eight volunteers living on a controlled diet and measured daily faecal microbial cell output during a basal period and then after speeding up transit pharmacologically with the drug Senokot or slowing it down with codeine phosphate. When transit was speeded up from 64 to $35 \mathrm{~h}$, microbial solids excretion rose from 16.5 to $20.3 \mathrm{~g} / \mathrm{d}$ and when it was slowed from 47 to $88 \mathrm{~h}$, microbial solids fell from 18.9 to $16 \cdot \mathrm{I} / \mathrm{g}$, results which suggest that transit may affect the efficiency of microbial metabolism in man also. Using the values shown in Fig. 2 it is possible to derive microbial cell yields for man in vivo since the daily output is known as is the loss of fermentable carbohydrate in the gut, assuming that the cell-wall polysaccharides from the three plant sources are the only additional substrate available to the bacteria. Microbial cell yields ( $\mathrm{g}$ cells $/ \mathrm{kg}$ carbohydrate fermented) are for cabbage 290 , carrot 220 and bran 360 . These values, despite the assumptions that have to be made in doing these calculations, are surprisingly similar to those derived during in vitro studies, and confirm the close qualitative parallels there are between the fermentative patterns of the human hind-gut and those of other animals including the ruminant.

\section{Importance of fermentation}

Given that the breakdown of complex carbohydrates in the human large intestine by the microflora is a normal part of colonic function, what is its significance? The quantitative importance of hind-gut fermentation is the subject of some debate. The major end-products are short-chain fatty acids which are rapidly absorbed from the human colon (McNeil et al. 1978; Ruppin et al. 1980) and therefore contribute to the host's energy metabolism. In the pig Partridge (1982) argues that the contribution to metabolizable energy of absorbed short- 
chain fatty acids is insignificant. In man if the only substrate for fermentation is dietary fibre then only $20 \mathrm{~g} / \mathrm{d}$ on average are broken down in subjects living on UK-type diets. Assuming that short-chain fatty acid absorption yields about $70 \%$ of the energy available had the carbohydrate been digested in the small intestine (Smith \& Bryant, 1979) the net energy yield is of the order of only $225 \mathrm{~kJ}$ or $2.5 \%$ of daily energy intake, an insignificant amount. If, however, there is more carbohydrate breakdown in the colon than just fibre from sources such as starch or mucus, and values from studies of microbial cell output in faeces and of breath hydrogen excretion after starch ingestion would suggest there is, then the contribution to energy metabolism will be proportionately greater. In countries where fermentable carbohydrate intakes are of the order of $100 \mathrm{~g} / \mathrm{d}$ or more (Bingham \& Cummings, 1980) short-chain fatty acids could be of considerable importance energetically.

Fermentation, by stimulating microbial growth, increases the requirements of micro-organisms for nitrogen. When dietary fibre intakes are increased in man faecal $\mathrm{N}$ excretion also increases (Calloway \& Kretsch, 1978; Kelsay et al. 1978). Much of the extra faecal $\mathrm{N}$ in both animals and man is due to increased microbial $\mathrm{N}$ excretion (Mason, 1969; Mason \& Palmer, 1973; Stephen \& Cummings, 1979). The main source of $\mathrm{N}$ in the colon is ammonia derived either from urea or protein. In the absence of active fermentation much of this ammonia is absorbed and passes to the liver where it is converted to urea. Vince et al. (1977) have shown, using human colonic microflora incubated anaerobically in vitro, that ammonia concentration falls when lactulose, a disaccharide, is added to the medium. In patients with cirrhosis of the liver, lactulose (which escapes digestion in the human small bowel) brings about a two to threefold increase in faecal $\mathrm{N}$ excretion and a decrease in urea production and urea pool size (Weber, 1979). Faecal ammonia levels fall in healthy human volunteers given fermentable carbohydrate (Cummings et al. 1981). Microbial breakdown of complex carbohydrates therefore leads to measurable changes in colonic $\mathrm{N}$ metabolism. The lowering of colonic ammonia concentration and absorption may be important in protection against carcinogenesis (Visek, 1972).

Short-chain fatty acids may have a significance other than simply that of their potential energy. Both the rumen and colonic epithelium metabolize short-chain fatty acids, especially butyrate and propionate. In the rumen these acids stimulate normal cell growth (Sander et al. 1959) and in man Roediger (1980a), using isolated colonic epithelial cells, has shown that n-butyrate is used for aerobic metabolism and suppresses glucose oxidation by $50 \%$. In further studies using the epithelial cells from patients with ulcerative colitis in remission, Roediger (1980b) has gone on to show that butyrate oxidation is reduced and suggests that this is a specific defect in metabolism which may be important in the aetiology of this common condition.

Butyrate also has antineoplastic properties. In cancer-cell studies it prolongs doubling time and reduces the rate of growth of human large bowel cancer cells (Kim et al. 1982; Kruh, 1982). It affects a wide range of cellular enzymes, may 
stabilize chromatin structure during cell division and suppress cell proliferation. Propionate, however, seems to be less important in maintaining the integrity of the colonic epithelium but is rapidly cleared by the liver where it may affect gluconeogenesis (Anderson \& Bridges, I982).

Potentially there are many other aspects of metabolism which may be affected by the breakdown of polysaccharides by the microflora in the colon. Complex carbohydrates are probably the main energy source for the fermentative bacteria so indirectly dietary intake of these polymers could affect the immune system, resistance to gut infection, steroid, mucus and enzyme metabolism (Gustafsson \& Eriksson, r 970; Gustafsson, 1982). What is not yet certain is the extent to which these aspects of metabolism are related to diet through fermentation and could be modified by changing food intakes.

\section{REFERENCES}

Anderson, J. W. \& Bridges, S. R. (1982). American fournal of Clinical Nutrition 35, 840.

Bingham, S. \& Cummings, J. H. (1980). In Medical Aspects of Dietary Fiber, pp. 261-284 [G. A. Spiller and R. M. Kay, editors]. New York: Plenum.

Bingham, S., Cummings, J. H. \& McNeil, I. (1979). American fournal of Clinical Nutrition 32, $1313-1319$.

Calloway, D. H. \& Kretsch, M. J. (1978). American fournal of Clinical Nutrition 31, I I $18-$ I 126.

Croucher, S. C., Houston, A. P., Bayliss, C. E. \& Turner, R. J. (1983). Applied and Environmental Microbiology 45, $1025^{-1033}$.

Cummings, J. H. (1978). Fournal of Plant Foods 3, 83-95.

Cummings, J. H. (1981). Gut 22, 763-779.

Cummings, J. H. (1982). In Colon and Nutrition, pp. 91-103 [H. Kasper and H. Goebell, editors]. Lancaster: MTP Press Ltd.

Cummings, J. H. (1983). In Nutrition and the Intestinal Flora, pp. 77-86 [B. Hallgren, editor]. Stockholm: Swedish Nutrition Foundation.

Cummings, J. H., Southgate, D. A. T., Branch, W. J., Wiggins, H. S., Houston, H., Jenkins, D. J. A., Jivraj, T. \& Hill, M. J. (1979). British Journal of Nutrition 41, 477-485.

Cummings, J. H., Stephen, A. M. \& Branch, W. J. (1981). In Banbury Report No. 7: Gastrointestinal Cancer: Endogenous Factors, pp. 71-81 [W. R. Bruce, P. Correa, M. Lipkin, S. R. Tannenbaum and T. D. Wilkins, editors]. Cold Spring Harbor, NY: Cold Spring Harbor Laboratory.

Doyle, R. B., Wolfman, M., Varso, D. \& Floch, M. H. (198I). American Fournal of Clinical Nutrition 34, 635 .

Drasar, B. S. \& Jenkins, D. J. A. (1976). American fournal of Clinical Nutrition 29, 1410-1416.

Drasar, B. S., Jenkins, D. J. A. \& Cummings, J. H. (1976). Fournal of Medical Microbiology 9, 423-431.

Eastwood, M. A., Baird, J. D., Brydon, W. G., Smith, J. H., Helliwell, S. \& Pritchard, J. L. (1982). In Dietary Fiber in Health and Disease, pp. $23-33$ [G. V. Vahouny and D. Kritchevsky, editors]. New York: Plenum.

Fuchs, H-M., Dorfman, S. \& Floch, M. H. (1976). American Journal of Clinical Nutrition 29, $1443-1447$.

Gustafsson, B. E. (1982). Scandinavian Fournal of Gastroenterology 77, I $17-131$.

Gustafsson, J-A. \& Eriksson, H. (1 970). Excerpta Medica International Congress Series no. 2 19, 323-327.

Heller, S. N., Hackler, L. R., Rivers, J. M., Van Soest, P. J., Roe, D. A., Lewis, B. A. \& Robertson, J. ( 1980$)$. American fournal of Clinical Nutrition 33, 1734-1 744.

Hespell, R. B. (1979). Federation Proceedings 38, 2707-271 2.

Hespell, R. B. \& Bryant, M. P. (1979). Fournal of Animal Science 49, $1640-1659$ 
Holloway, W. D., Tasman-Jones, C. \& Bell, E. (1980). American Journal of Clinical Nutrition 33, $260-263$.

Holloway, W. D., Tasman-Jones, C. \& Lee, S. P. (1978). American Fournal of Clinical Nutrition $31,927 \rightarrow 930$.

Holloway, W. D., Tasman-Jones, C. \& Maher, K. (1983). American Yournal of Clinical Nutrition $37,253-255$.

Isaacson, H. R., Hinds, F. C., Bryant, M. P. \& Owens, F. N. (1975). Journal of Dairy Science 58, I645-1659.

Kelsay, J. L., Behall, K. M. \& Prather, E. S. (1978). American Fournal of Clinical Nutrition 3 r, I $149-1$ I 53

Kim, Y. S., Tsao, D., Morita, A. \& Bella, A. (1982). In Colonic Carcinogenesis, Falk Symposium 3I, pp. 317-323 [R. A. Malt and R. C. N. Williamson, editors]. Lancaster: MTP Press Ltd.

Kotarski, S. F. \& Salyers, A. A. (1981). Fournal of Bacteriology 146, 853-860.

Kruh, J. (1982). Molecular Cell Biochemistry 42, 65-82.

McLean-Ross, A. H., McKay, L. F., Busuttil, A., Anderson, B. M. W., Brydon, W. G. \& Eastwood, M. A. (1981). Proceedings of the Nutrition Society 40, $73 \mathrm{~A}$.

McNeil, N. I., Bingham, S., Cole, T. J., Grant, A. M. \& Cummings, J. H. (1982). British fournal of Nutrition $47,407-4$ I 5 .

McNeil, N. I., Cummings, J. H. \& James, W. P. T. (1978). Gut 19, 819-822.

Mangold, E. (1934). Nutrition Abstracts and Reviews 3, 647-655.

Mason, V. C. (1969). Fournal of Agricultural Science 73, 99-1 11.

Mason, V. C. \& Palmer, R. (1973). Acta Agriculturae Scandinavica 23, $141-150$.

Miller, T. L. \& Wolin, M. J. (1979). American fournal of Clinical Nutrition 32, 164-1 72.

Moore, W. E. C., Cato, E. P. \& Holdeman, L. V. (1978). American fournal of Clinical Nutrition $3 \mathrm{I}, \mathrm{S}_{33}-\mathrm{S}_{42}$.

Owens, F. N. \& Isaacson, H. R. (1977). Federation Proceedings 36, 198-202.

Partridge, I. G. (1982). In Digestive Physiology in the Pig, pp. $217^{-223}$ []. P. Laplace, T. Corring and $A$. Rerat, editors]. Paris: Institut National de la Recherche Agronomique.

Prynne, C. J. \& Southgate, D. A. T. (1979). British fournal of Nutrition 41, 495-503.

Ritchie, J. L. (1971). Gut 12, 528-540.

Roediger, W. E. W. (r $980 a)$. Gut $21,793-798$.

Roediger, W. E. W. (1980b). Lancet ii, $712-715$.

Ruppin, H., Bar-Meir, S., Soergel, K. H., Wood, C. M. \& Schmitt, M. G. (1980). Gastroenterology 78 , I $500-1507$.

Salyers, A. A. (1983). In Nutrition and the Intestinal Flora, pp. $35-44$ [B. Hallgren, editor]. Stockholm: Almquist und Wikseh International.

Salyers, A. A., Arthur, R. \& Kuritza, A. (I $98 \mathrm{I}$ ). Yournal of of Agricultural and Food Chemistry 29, $475-480$.

Sandberg, A-S., Andersson, H., Hallgren, B., Hasselblad, K. \&c Isaksson, B. (1981). British Fournal of Nutrition $45,283-294$.

Sander, E. G., Warner, R. S., Harrison, H. N. \& Loosli, J. K. (1959). Fournal of Dairy Science 42, I600-I605.

Smith, C. J. \& Bryant, M. P. (1979). American fournal of Clinical Nutrition 32, 149-157.

Southgate, D. A. T. (1976). Determination of Food Carbohydrates. London: Applied Science Publishers Ltd.

Southgate, D. A. T., Branch, W. J., Hill, M. J., Drasar, B. S., Walters, R. L., Davies, P. S. \& Baird, I. M. (1976). Metabolism 25, $1129-1135$.

Stephen, A. M. \& Cummings, J. H. (1979). Proceedings of the Nutrition Society 38, ${ }_{4}$ I A.

Stephen, A. M. \& Cummings, J. H. (1 $980 a$ ). Fournal of Medical Microbiology 1 3, 45-56.

Stephen, A. M. \& Cummings, J. H. (1 $980 b)$. Nature $284,283-284$.

Stephen, A. M. \& Cummings, J. H. (I 88 I). Gastroenterology 80, 1294.

Vince, A., Killingley, M. \& Wrong, O. M. (1977). Gastroenterology 74, 544-549.

Visek, W. J. (1972). Federation Proceedings 31, 1 I 78 - I 193.

Walters, R. L., Baird, I. M., Davies, P. S., Hill, M. J., Drasar, B. S., Southgate, D. A. T., Green, J. \& Morgan, B. (1975). British Medical fournal ii, 536-538.

Weber, F. L. (1979). Gastroenterology 77, 5 18-523.

Werch, S. C. \& Ivy, A. C. (194I). Fournal of Digestive Diseases 8, $10 \mathrm{I}-\mathrm{I}_{5}$. 
Williams, R. D. \& Olmsted, W. H. (1936). Journal of Nutrition I I, 433-449.

Wrong, O. M. (1971). British Postgraduate Federation Scientific Basis of Medicine Annual Reviews, pp. 192-21 5. London: Athlone Press.

Wyman, J. B., Heaton, K. W., Manning, A. P. \& Wicks, A. C. B. (1978). Gut 19, 146-150. 